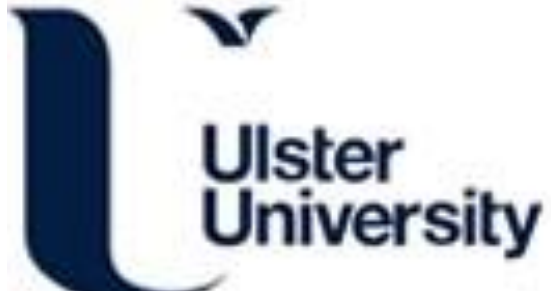

\section{New directions for carbon-based detectors: exploiting the versatility of carbon substrates in electroanalysis}

Villalba, MM., \& Davis, J. (2008). New directions for carbon-based detectors: exploiting the versatility of carbon substrates in electroanalysis. Journal of Solid State Electrochemistry, 12(10), 1245-1254. https://doi.org/10.1007/s10008-008-0535-1

Link to publication record in Ulster University Research Portal

\section{Published in:}

Journal of Solid State Electrochemistry

Publication Status:

Published (in print/issue): 01/10/2008

DOI:

10.1007/s10008-008-0535-1

\section{Document Version}

Publisher's PDF, also known as Version of record

\section{General rights}

Copyright for the publications made accessible via Ulster University's Research Portal is retained by the author(s) and / or other copyright owners and it is a condition of accessing these publications that users recognise and abide by the legal requirements associated with these rights.

\section{Take down policy}

The Research Portal is Ulster University's institutional repository that provides access to Ulster's research outputs. Every effort has been made to ensure that content in the Research Portal does not infringe any person's rights, or applicable UK laws. If you discover content in the Research Portal that you believe breaches copyright or violates any law, please contact pure-support@ulster.ac.uk. 


\title{
New directions for carbon-based detectors: exploiting the versatility of carbon substrates in electroanalysis
}

\author{
Maria Marti Villalba • James Davis
}

Received: 17 February 2008 / Accepted: 19 February 2008 /Published online: 28 March 2008

(C) Springer-Verlag 2008

\begin{abstract}
The different approaches that have been taken in the development of electrochemical detectors incorporating carbon as the principal electrode substrate are reviewed. The multitude of forms that carbon can take provides an extremely versatile platform upon which to enhance the detector performance. The different approaches that have been taken in recent years have been critically appraised and the emergence of new composite technologies is highlighted. The role of carbon and the applications to which it has been employed are presented and compared and contrasted within the remit of electroanalytical investigations.

Keywords Chromatography $\cdot$ LC-ED · FIA · Detectors · Electroanalysis

\begin{tabular}{ll}
\multicolumn{2}{l}{ Abbreviations } \\
GC & glassy carbon \\
CF & carbon fibre \\
RVC & reticulated vitreous carbon \\
HOPG & highly orientated pyrolytic graphite \\
eppg & edge plene pyrolytic graphite \\
bppg & basal plane pyrolytic graphite \\
CNTs & carbon nanotubes \\
CMEs & chemically modified electrodes \\
SWCNT & single-wall carbon nanotube \\
MWCNT & multi-walled carbon nanotube \\
SPE & screen-printed electrode \\
LC & liquid chromatography \\
Cyt C & cytochrome C
\end{tabular}
\end{abstract}

M. M. Villalba $(\bowtie) \cdot J$. Davis

School of Biomedical and Natural Sciences,

Nottingham Trent University,

Nottingham NG11 8NS, UK

e-mail: maria.marti@ntu.ac.uk

$\begin{array}{ll}\text { OPP } & \text { over-oxidised polypyrrole } \\ \text { GOD } & \text { glucose oxidase } \\ \text { HAO } & \begin{array}{l}\text { histamine oxidase } \\ \text { choline oxidase }\end{array} \\ \text { ChOD } & \text { glutamate oxidase } \\ \text { GlutaOD } & \text { NADH oxidase } \\ \text { NOX } & \text { glutamate dehydrogenase } \\ \text { GluDH } & \text { xanthine oxidase } \\ \text { XOD } & \text { Prussian blue } \\ \text { PB } & \text { methyl-patanthion } \\ \text { MPT } & \text { ascorbic acid } \\ \text { AA } & \text { horseradish peroxidase } \\ \text { HRP } & \text { pyrrolquinoline quinone } \\ \text { PQQ } & \text { immunoglobulin G } \\ \text { IgG } & \text { not applicable } \\ \text { N/A } & \end{array}$

\section{Introduction}

The combination of electrochemical detection with liquid chromatographic techniques (LC-ED) has proven to be one of the more versatile analytical options when attempting to characterise complex matrices. The detectors have taken many forms and have exhibited sensitivities that can compliment or in many instances outperform conventional ultraviolet (uv) spectroscopic techniques [1-14]. They can offer greater procedural simplicity than fluorimetric systems [15-19] and are significantly less expensive, both to procure and operate, than mass spectroscopic detection (LC-MS) [20-24]. While the sensitivities, resolutive capacity and structure determination capabilities of the latter procedure are undeniably impressive, LC-ED techniques have sought to fulfil more the demands required by routine determinations without compromising selectivity. Signifi- 
cant improvements in performance have been realised through the modification of the detector surfaces to confer greater sensitivity in particular applications[1-3, 25]. The aim of the present review is to provide a critical evaluation of the roles that carbon can play in the construction of LC detectors and to give some insights into present and future applications.

While carbon has long been recognised as a versatile substrate in electroanalysis - its use in liquid chromatographic systems has been relatively understated. The emphasis of the present investigation is solely on the post-column analysis and detector design-construction highlighting the potential opportunities that carbon-in its many varied forms - can provide for LC-ED systems. The various modifications that can be undertaken to enhance detector performance and the emergence and potential impact of new composite materials are considered in the following sections.

\section{Core detector design}

Electrochemical detectors generally take one of three core design formats and relate principally to how the working electrode is arranged with respect to the direction of the mobile phase flow. Schematics outlining these are detailed in Fig. 1. The simplest relates to the insertion of a planar electrode within the flow system operation. This can be extended to porous carbon systems (typically pyrolytic graphite) that encompass the entire diametre of the flow channel. The latter systems are designed more for coulometric analysis in which the complete conversion of the analyte can be achieved $[1,2]$. The third design inserts the electrode perpendicular to the flow (wall jet). Each methodology has its merits depending on the nature of the electrode being used and there will always be variations in the design of the cell used within research environments. The construction of arrays introduces an extra dimension to those already outlined in Fig. 1 and can greatly enhance the

a

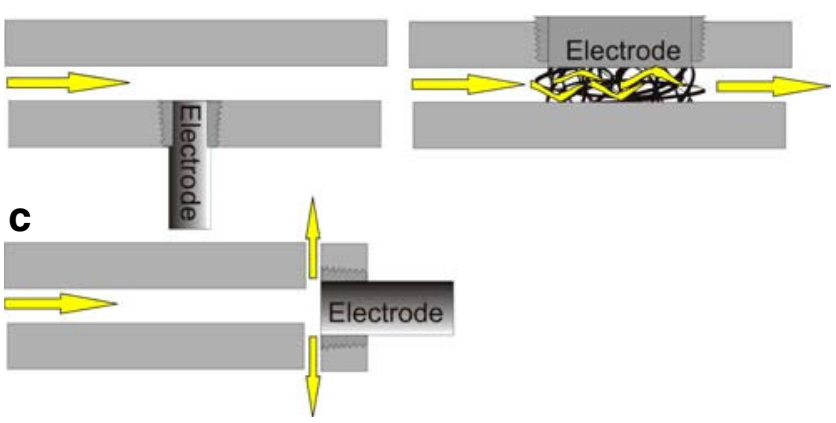

selectivity allowing post-column resolution at the detector. Multiple detectors placed in series, each set at a different operating potential, can offer multi-dimensional analysis and is analogous to the diode array detectors though at considerably less expense. Hence, two or more analytes eluting at same time can be resolved at the detection array as a consequence of their potential dependent responses at each electrode. Thus, in a recent example, a single chromatographic signal arising from a conventional uvvisible detector was subsequently shown to possess more than 300 discrete components when resolved using a fourchannel coulometric detector [2].

It has long been recognised that different electrode substrates (even when poised at identical operating potentials) can elicit significantly different responses from a given analyte. As a result, post-column electrochemical detectors have exploited a variety of electrode substrates (Pt, Au, Ag, C, Cu, Ni) and modified systems (alloys, organometallic catalysts, enzymes) to improve analytical performance [1,3]. Carbon can be viewed as the most flexible of these substrates as a consequence of the variety of physical forms it can take but each of these can come with a diverse range of chemical properties (or functionalities) that can allow detector enhancements through a surface modification. In this respect, carbon is a significantly more flexible diagnostic tool.

\section{Carbon: a versatile substrate}

The multitude of physical forms that carbon can take allows for considerable flexibility in the design of the detector. Glassy carbon (GC), carbon aerogels, carbon fibre (CF), carbon felts, reticulated vitreous carbon (RVC) or graphite have all been used in a great number of analytical techniques [25]. Highly orientated pyrolytic graphite (HOPG) offering edge plane (eppg) and basal plane (bppg) morphologies are frequently used to explore the more fundamental side of electron transfer processes but can be of considerable value in LC-ED systems. The basal and edge plane possess different properties with the latter morphology tending to exhibit considerably faster electrode kinetics and, as a consequence, possesses the potential for greater detection sensitivities [26-29]. The edge plane sites on carbon nanotubes (CNTs) are also thought to be a major contributor to the high electron transfer rates and electrocatalytic effects observed in such systems [26, 29]. Glassy carbon is however the most commonly employed electrode material in electroanalysis and is easily adapted for use in the detector designs outlined in Fig. 1. Different studies reporting the use of carbon electrodes coupled with flow systems are presented in Table 1 and highlight the diversity of application to which carbon could be utilised and 
Table 1 Different applications of carbon electrodes

\begin{tabular}{|c|c|c|c|c|}
\hline Form & Analyte & Application & Detection limits $(\mu \mathrm{M})$ & Ref \\
\hline GC & Rocuronium impurities & Pharmaceutical & $0.094-235$ & [9] \\
\hline Carbon fibre micro-disk (CFE) & Herb Acanthopanax senticosus & Environmental & $10-1.5$ & [10] \\
\hline GC & Ag-ions & Biochemistry & $20-67$ & [11] \\
\hline eppg & Thiols & Bioanalytical & $1.7-2.7$ & [27] \\
\hline eppg & Sulphide & Analytical & $4.9-10$ & [28] \\
\hline
\end{tabular}

provides an indication of the detection limits than can be achieved at the unmodified electrode surfaces.

Surface modification

The surface of carbon can be modified by mechanical [2830], electrochemical [31-38], chemical [38-45] or thermal [46] means - the aim being to alter the interfacial reactivity of the base substrate and thereby improve the detector performance. In this review, surface modification is categorised in three levels. The first level is simply a modification of the species already present on the surface (Fig. 2a); on the second level - the modification implies the attachment of exogenous species onto the electrode surface (Fig. 2b); and in the last level, the species are intercalated between the graphene layers of the base substrate (not shown). The latter level can be induced through the electrochemical pre-treatment processes as a result of carbon fracturing $[31,36,41]$. The activation of the electrode is a term that is frequently used to describe a variety of superficial processes: the elimination of electrode's impurities, the creation of a fresh electrode surface, the increase of surface functional groups or an increase in
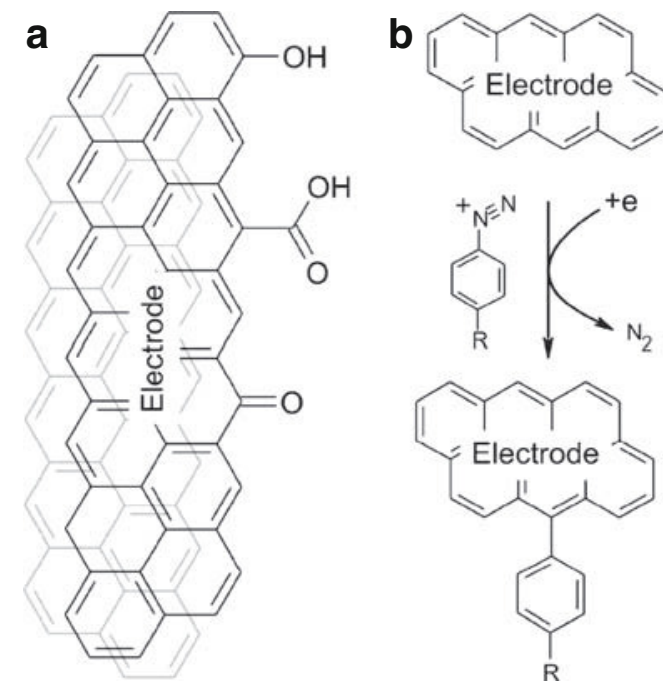

Fig. 2 a Carbon functionalities and b surface activation electrode area. Mechanical activation such as polishing or sonication is widely used to clean the electrode and to expose fresh electrode area but can have the beneficial effect of increasing the availability of edge sites [27, 29] that can, as with eppg electrodes, serve to increase sensitivity. The most usual activation technique involves the electro-oxidation of the carbon surface by applying a fixed anodic or cyclic potential. The oxidation increases the proportion of oxygen species (Fig. 2a) such as hydroxyl, carbonyl, carboxyl and quinones at the electrode surface [38]. These are well known to influence the wettability, surface reactivity, porosity and conductivity of the electrode [25, 31, 32, 34].

Chemically modified electrodes signify a more elaborate approach to surface modification and generally involve the deliberate attachment of new chemical components. This offers greater control over the electrochemical behaviour given the greater variety of functionality that can be introduced onto the surface-more so than that obtained by the activation of the intrinsic functionalities described previously. Three general approaches can be takenformation of covalent bonds [42-45] and irreversible adsorption [41]. Electrochemically induced functionalisation of surfaces by exogenous species can also be utilised and provides an effective alternative to purely chemical methods. A more recent strategy involves the reduction of diazo species (shown in Fig. 2b) whereby there is the direct covalent attachment of the target species [36, 37, 41, 43]. The most commonly adopted procedure is however immobilisation of chemical species in a polymer film onto the carbon surface [46-91] and this will be considered in more detail in the following section. Irrespective of the procedure, the modifications can be used to good effect to influence hydrophilicity-hydrophobicity of the interface and thereby alter the adsorption characteristics of the matrix components - facilitating the accumulation of one species over another and thereby improving electroanalytical discrimination $[25,30,31,32,34]$. Alternatively, electrocatalytically active molecules or mediators bonded to the electrode surface can act as electron transfer bridges between the electrode and electroactive species in solution $[55,60,70]$ and thereby modify the electrode properties of 
the base electrode. Some of the possible surface modifications and their application are detailed in Table 2.

\section{Polymer coatings}

The use of polymers as a coating material has been used extensively to enhance the electrode performance and represents the most common approach to electrode modification [73]. The chemical and physical properties of the polymer will substantially influence the electrode response characteristics with the underlying carbon normally acting as a support material and the electrical conduit. In many cases, the form of carbon utilised will be determined more by availability and by detector design considerations. This is not, however, to suggest that the inherent electrochemical properties of the base material can simply be ignored as it is still important to establish fast electrode kinetics [28, 30] between the substrate and the electroactive material within the polymer. The dimensions (micro, macro, fibre), porosity, mechanical integrity and processing capability of the base substrate and the ease with which it can be incorporated within a flow cell will often be considerable factors in selecting the base substrate. The versatility of carbon in this respect contrasts the use of metal electrodes as the detecting substrate where the physical forms available are more restrictive. Glassy carbon, reticulated vitreous carbon [25] and pyrolytic graphite [30] are the most common electrodes in comparison to other carbon materials though polymer encapsulated carbon fibre systems have grown in popularity in recent years [50-53]. The latter carbon material can be rationalised in terms of the greater dimensional compatibility of the fibre systems within conventional LC architectures.

Numerous polymeric systems have been investigated and can be placed within several broad categories: nonconducting [54-63], conducting [64-83] and redox gels [84-88]. While a large variety of systems have been examined-the most common and arguably the most successful tend to be those based on $\operatorname{Nafion}^{\circledR}[59,60]$, polyaniline derivatives [64-74] and polypyrrole [51, 75-83]. The first falls across the pre-formed and non-conducting categories of polymer modification and possess important anionic properties that can confer significant ion exchange properties to amperometric detectors. This is also true of the pyrrole and aniline systems but these possess the added advantage of being formed through electropolymerisation and hence offer greater control over polymer morphology (thickness, permeability etc.) and also the spatial localisation of the film. The latter advantage is important given the increasing interest in miniaturised systems where the conventional solvent casting techniques common to $\mathrm{Nafion}^{\circledR}$ would not be appropriate. Some of the applications in which polymer-modified carbon electrodes play a central role are detailed in Table 3.

The conducting polymers, especially those based upon pyrrole, can serve as an extremely flexible diagnostic tool offering a number of roles-electrocatalysis, molecular filter, enzyme entrapment etc. [51, 81-83]. Polypyrrole can be over-oxidised resulting in a loss of conductivity and the expulsion of the dopant ions [81-83, 69]. In such instances, it has been shown to possess cation exchange (as opposed to the anion exchange when in the conductive

Table 2 Surface-modified electrode and their application

\begin{tabular}{|c|c|c|c|c|c|}
\hline Form & Analyte & Pre-treatment-modification & Application & $\begin{array}{l}\text { Detection } \\
\text { limit }(\mu \mathrm{M})\end{array}$ & Ref \\
\hline $\mathrm{GC}$ & $\begin{array}{l}\text { 5-Hydroxyindoleacetil } \\
\text { 5-Hydroxytryptamine }\end{array}$ & $\begin{array}{l}\text { Electrochemical oxidation } \mathrm{H}_{2} \mathrm{SO}_{4} \\
\text { Gold adsorption }\end{array}$ & Urine & $\begin{array}{l}0.0005 \\
0.00025\end{array}$ & [13] \\
\hline $\mathrm{GC}$ & $\mathrm{H}^{+}$ & Electrochemical oxidation $\left(\mathrm{NH}_{4}\right)$ & $\mathrm{pH}$ sensor & N/A & [31] \\
\hline GC & Vitamins $\mathrm{B}_{2}, \mathrm{~B}_{6}, \mathrm{C}$ & $\begin{array}{l}\text { Electrochemical oxidation } \\
\text { phosphate-buffered salt (PBS) }\end{array}$ & Multi-vitamin tablets & $\mathrm{N} / \mathrm{A}$ & [32] \\
\hline Carbon paste & Phenol & Electrochemical oxidation $\mathrm{NaOH}$ & Tap and waste water & N/A & [33] \\
\hline $\mathrm{GC}$ & $\mathrm{Mn}$ & $\mathrm{NH}_{3}-\mathrm{NH}_{4} \mathrm{Cl}$ & Lake water & 0.001 & [34] \\
\hline Carbon film & Glucose & Electrochemical oxidation PBS & Wines & 27 & [35] \\
\hline GC & Dopamine & Electrochemical oxidation PBS & Urine & 0.008 & {$[36]$} \\
\hline SPE & Organophosphate & $\begin{array}{l}\text { Covalent bond (electrochemical reduction } \\
\text { of 4-nitrobenzene) and enzyme attachment }\end{array}$ & & 0.0001 & [37] \\
\hline $\mathrm{GC}$ & Erythromycin & Electrochemical oxidation $\mathrm{NH}_{3}-\mathrm{NH}_{4}$ & Tablets & N/A & [41] \\
\hline GC & Guanine, adenine & Covalent bond $r$-aminobenzene & Thiocholine & 0.03 & [42] \\
\hline GC & Uric acid & Covalent bond $-\mathrm{N}^{+}\left(\mathrm{CH}_{3}\right)$ & Urine & 0.02 & [43] \\
\hline Carbon paste & Riboflavin & Covalent-bound aza macro-cycles & Pharmaceutical preparations and food & $\mathrm{N} / \mathrm{A}$ & [45] \\
\hline
\end{tabular}


Table 3 Applications of polymer-modified electrodes

\begin{tabular}{|c|c|c|c|c|c|}
\hline Polymer & Analyte & Modifier & Application & $\begin{array}{l}\text { Detection limit } \\
(\mu \mathrm{M})\end{array}$ & Ref \\
\hline Polypyrrole & Nitrate & Nitrate, parylene & Potentiometric in situ nitrate biosensor & 50 & [53] \\
\hline Poly(L-arginine) & $\begin{array}{l}\text { Epinephrine } \\
\text { Dopamine }\end{array}$ & L-Arginine & Simultaneous determination & $\begin{array}{l}0.7 \\
0.3\end{array}$ & {$[54]$} \\
\hline Melanin & Dopamine & N/A & N/A & 0.005 & [55] \\
\hline L-Cysteine & Metal ions & N/A & N/A & N/A & {$[56]$} \\
\hline Titania-sol-gel & Glucose & $\mathrm{GOD} / \mathrm{FcPF}_{6}$ & Serum glucose & $\mathrm{N} / \mathrm{A}$ & {$[57]^{\mathrm{a}}$} \\
\hline $\begin{array}{l}\text { Eastman Kodak } \\
\text { AQ55 }\end{array}$ & $\mathrm{X}^{-}$ & Cyt C & Electrocatalysis studies & $\mathrm{N} / \mathrm{A}$ & {$[58]$} \\
\hline Nafion $^{\circledR}$ & $\mathrm{X}^{+}$ & $\mathrm{Fe}^{2+}, \mathrm{Fe}^{3+}$ & N/A & $<1$ & [59] \\
\hline Tosflex & $\mathrm{X}^{-}$ & $\mathrm{Fe}(\mathrm{CN})_{6}^{4-}, \mathrm{Fe}(\mathrm{CN})_{6}^{3}$ & N/A & $<1$ & {$[59]$} \\
\hline Nafion $^{\circledR}$ & MPT & NiTSPc & Organophosphates & $1-50 \mathrm{ng} 7 \mathrm{ml}$ & {$[60]^{\mathrm{a}}$} \\
\hline Methyl silicate & & Antimony-doped tin oxide (ATO) & $\begin{array}{l}\text { Transparent and conductive } \\
\text { electrodes }\end{array}$ & N/A & {$[61]$} \\
\hline$o$-Aminophenol & NADH & NADH detection & N/A & 0.15 & {$[65]$} \\
\hline$o$-Phenylenediamine & Paracetamol & Copolymer aniline & N/A & $1 . .5$ & {$[66]$} \\
\hline Poly-toluidine blue & $\mathrm{NADH}$ & Electro-oxidative polymerisation & N/A & 0.1 & {$[70]^{\mathrm{a}}$} \\
\hline L-Arginine & Epinephrine Dopamine & $\mathrm{N} / \mathrm{A}$ & Human urine & 2.93 & [71] \\
\hline Polyaniline & $\mathrm{H}_{3} \mathrm{O}^{+}$ & N/A & $\mathrm{pH}$ measurements & $\mathrm{N} / \mathrm{A}$ & {$[72]$} \\
\hline Polyaniline & & PB-oxidase & Oxidase biosensors & N/A & {$[73]^{\mathrm{a}}$} \\
\hline Polyaniline & Choline & MWNTs & N/A & 0.3 & [74] \\
\hline Polypyrrole & $\mathrm{Ag}^{+}$ & Sulphonated calixarenes & $\mathrm{Ag}^{+}$ & N/A & {$[75]$} \\
\hline Pyrrole-co-pyrrole & Phenol & $\begin{array}{l}\text { Amine and } p \text {-toluene } \\
\text { sulphonated anions }\end{array}$ & Phenol & $\mathrm{N} / \mathrm{A}$ & {$[76]$} \\
\hline Polypyrrole & $\mathrm{O}_{2}^{-}$ & Anthraquinone(s) & Energy conversion systems & N/A & {$[77]$} \\
\hline Polypyrrole & $\mathrm{AA}$ & $\mathrm{FCN}-\mathrm{Fe}-\mathrm{Fe}_{3} \mathrm{O}_{4}$ & AA in water samples & 150 & {$[78]$} \\
\hline Pyrrole & $\mathrm{H}_{2} \mathrm{O}_{2}$ & $\mathrm{HRPFe}(\mathrm{CN})_{6}^{4-} \mathrm{Fe}(\mathrm{CN})_{6}^{3-}$ & Hydrogen peroxide biosensors & N/A & {$[79]$} \\
\hline OPP & Catecholamines & Au nano-clusters & Human blood-serum & N/A & {$[83]$} \\
\hline PQQ & Glucose & Glucose dehydrogenase & Independence of $\mathrm{O}_{2}$ & $\mathrm{~N} / \mathrm{A}$ & {$[84]$} \\
\hline Os-gel-HRP & Histamine & $\mathrm{HAO}$ & $\mathrm{N} / \mathrm{A}$ & $\mathrm{N} / \mathrm{A}$ & {$[85]^{\mathrm{a}}$} \\
\hline Os-gel-HRP & $\begin{array}{l}\text { Glucose, choline } \\
\text { glutamate }\end{array}$ & GOD-ChOD-GlutaOD & N/A & 0.01 & {$[86]$} \\
\hline Os-gel-HRP & Hypoxanthine & XOD & N/A & 2 & {$[87]^{\mathrm{a}}$} \\
\hline Os-gel-HRP & Glutamate & GluDH-NOX & N/A & 0.02 & {$[88]^{\mathrm{a}}$} \\
\hline
\end{tabular}

${ }^{\mathrm{a}}$ Coupled with flow systems

state) and molecular filter properties. This has been shown to impart enhanced selectivity and sensitivity toward neurotransmitter analytes. They also confer the advantage of being able to detect those species that would not normally be electrochemically accessible. This relates to the exchange of the charged species within the cationic film (as counter ions) which alters the conductivity of the polymer backbone and thereby gives rise to the analytical signal [73].

Pre-formed redox gels consist of the other main polymer grouping and almost invariably incorporate osmium complexes [85-88]. The gel serves to both entrap the enzyme at the electrode surface and relay electrons from the carbon surface to the redox centre within the protein. The basis mechanism is highlighted in Fig. 3 using an example of peroxide reduction in which an osmium gel (Os-gel)- horseradish peroxidase is employed. Hydrogen peroxide is reduced enzymatically by the immobilised enzyme which in turn is converted to the oxidised form. It is re-activated by the transfer of electrons from the electrode but which are transported via the osmium shuttles (Os(III) $\leftrightarrow \mathrm{Os}(\mathrm{II})$ ). The

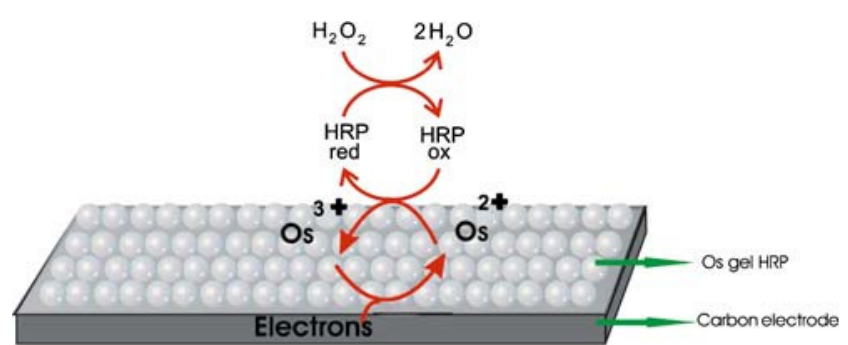

Fig. 3 Redox gel reaction scheme 
Table 4 Carbon composite electrodes and their applications

\begin{tabular}{|c|c|c|c|c|c|}
\hline Binder & Analyte & Modification & Applications & Detection limit $(\mu \mathrm{M})$ & Ref \\
\hline Nujol & Tryptophan & MWCNT-cobalt salophen & Human serum & 0.1 & [89] \\
\hline Mineral oil & Cadmium & 1-Furoylthioureas & Cadmium determination & $60 \mu \mathrm{mg} / 1$ & [90] \\
\hline Paraffin oil & Sugars and AA & Polyethylene glycol and $\mathrm{Cu}_{2} \mathrm{O}$ & Biological samples & 0.X & {$[93]^{\mathrm{a}}$} \\
\hline Olive oil & Phenols & NA & Extra virgin olive oils & N/A & {$[94]$} \\
\hline Paraffin & Phenol & Montmorillonite & Tap water & 0.05 & [95] \\
\hline Paraffin oil & Anion & Ferrocene functionalised Calyx[4]pyrrole & Water & $<0.1$ & {$[96]$} \\
\hline Wax & Hydrazine & Manganese hexacyanoferrate & Photographic developer & 6.65 & {$[98]^{\mathrm{a}}$} \\
\hline
\end{tabular}

${ }^{\text {a }}$ Coupled with flow systems

gels possess generic applicability allowing a host of enzyme systems to be used. A number of examples are highlighted in Table 3. The main drawback however is the fact that it requires the Os-gel to be cast onto the electrode surface [84-88].

\section{Carbon composite electrodes}

Composite electrodes typically consist of two or more components which together form the bulk of the base substrate. The composition of this group can be incredibly diverse depending on definition but, in general, the field can be sub-divided into carbon paste [89-109] and screenprinted [110-118] systems. Despite the different formats and processing requirements - both share a common methodology in which carbon particles are bound together by a binder. The great strength of this approach is the fact that the composition - and hence properties - of the electrode can be easily manipulated by altering one or more of the components in the paste or ink or by the simple addition of a catalyst or other modifier during the initial mixing phase. Both systems have been used in LC applications and each approach can confer particular operational advantages.

Carbon paste electrodes typically rely upon carbon particles being held together by an impregnated organic liquid phase that is compacted into a holder and can then be used in much the same way as a conventional solid electrode and likewise can be incorporated within flow systems in much the same way as a commercial glassy carbon or HOPG electrode [89-98]. Their application within such is however less common-as indicated in Table 4. This is rather surprising as-irrespective of the particular form of carbon used - the paste electrodes can be rapidly constructed with little expense beyond the initial cost of the components. As such, they can facilitate a prototyping function that allows the ad hoc production of modified electrodes. Operationally, the paste electrodes can have the advantage of providing a low background compared to solid graphite and noble metal electrodes. They are also renewable in that, upon fouling, the surface can be regenerated by polishing $[89,93]$. There is clearly the potential for a huge number of variations in the preparation - the form of carbon used, the nature of the binder and presence of modifiers or catalysts. The binder can take the form of a simple mineral oil (nujol or paraffin) [89-98], wax or epoxy [98], polymers [67] or ionic liquid [99].

CNTs have risen to considerable prominence in recent years and have been widely investigated (Table 5) as an electrode modifier or as a direct replacement for the more traditional graphitic powder [100-109]. The duality of construction emphasises the versatility of the material.

Table 5 Carbon nanotubes electrodes and their applications

\begin{tabular}{lllrr}
\hline Analyte & Modification & Applications & Detection limit $(\mu \mathrm{M})$ & Ref \\
\hline Nitrite, AA, uric acid & Polypyrrole & N/A & N/A & {$[72]$} \\
Homocysteine & Nafion ${ }^{\circledR}, \mathrm{CNT}$ & N/A & 0.06 & 10 \\
Galactose & Nafion ${ }^{\circledR} / \mathrm{CNT}$ & Carbohydrate detection & {$[103]^{\mathrm{a}}$} & {$[104]^{\mathrm{a}}$} \\
Chlorate, iodate, bromate & MWCNT-iron (III)-porphyrin & Chlorate, iodate, bromate & $0.5,2,0.001$ & {$[105]$} \\
Estradiol & Nafion ${ }^{\circledR} / \mathrm{Ni}(\mathrm{Cyclam})$ & Serum & 0.06 & {$[106]$} \\
Glucose & PtPbNP & Blood & N/A & 17 \\
$\mathrm{H}_{2} \mathrm{O}_{2}$ & $\mathrm{Nafion}^{\circledR}-\mathrm{Au}-\mathrm{GOD}$ & Beverages & N/A & {$[107]$} \\
$\mathrm{NH}_{3}$ & $\mathrm{SiO}_{2}-\mathrm{Si}-\mathrm{Li}$ & N/A & & {$[108]$} \\
\hline
\end{tabular}

${ }^{\mathrm{a}}$ Coupled with flow systems 
Table 6 Screen-printed electrodes and their applications

\begin{tabular}{lllll}
\hline Analyte & Modification & Applications & Detection limit $(\mu \mathrm{M})$ & Ref $^{-}$ \\
\hline $\mathrm{H}_{2} \mathrm{O}_{2}$ & HRP & N/A & N/A & {$[111]^{\mathrm{a}}$} \\
Organophosphates & Tyrosinase & River water & N/A & {$[112]$} \\
Nitric oxide & Direct oxidation & Biological samples & N/A & {$[110]^{\mathrm{a}}$} \\
$\mathrm{H}_{2} \mathrm{O}_{2}$ & GOD & Glucose & N/A & {$[107]$} \\
$\mathrm{Glucose}$ & Nsmium complex & N/A & N/A & {$[114]^{\mathrm{a}}$} \\
$\mathrm{AA}$ & $\mathrm{Fe}(\mathrm{CN})_{6}^{4-}, \mathrm{Fe}(\mathrm{CN})_{6}^{3-}$ & N/A & $3 \mathrm{ng} / \mathrm{ml}$ & {$[115]^{\mathrm{a}}$} \\
$\mathrm{IgG}$ & Antigen-antibody & Immuno-enzyme & N/A & {$[116]^{\mathrm{a}}$} \\
$\mathrm{Sulphide}$ & Cinder/hexacyano cobaltate & N/A & 0.99 & {$[117]^{\mathrm{a}}$} \\
$\mathrm{H}_{2} \mathrm{O}_{2}$ & Copper & N/A & {$[118]^{\mathrm{a}}$} \\
\hline
\end{tabular}

${ }^{\text {a }}$ Coupled with flow systems

The nanotubes can generally be found in two forms: single wall (SWCNT) or multi-walled (MWCNT) and, by analogy to graphite, the walls of the nanotube can be defined as basal plane while the ends are considered to be edge plane. It has been demonstrated that the edge plane effects, often in combination with increased oxygen functionalities, are largely responsible for the enhanced electrode kinetics [28, 30]. Reviews covering the breadth of nanotube application and the fundamentals that underpin their action are widely available. In common with the paste systems, they have the notable benefit of decreasing the capacitive background which increases the sensitivity of the electrode [103]. As in the case of the carbon paste systems, the exploitation of nanotubes within flow systems is more limited despite the considerable advantages they can potentially confer. This is likely to be a consequence of the field being relatively young and it could be expected that more electrode designs incorporating nanotubes will emerge in the future.

Screen-printed electrodes are generally inexpensive to fabricate when considering large-scale processing in which the costs of individual electrodes can be expected to fall dramatically. Access to such facilities and the large volumes of the reagents required can however be prohibitiveespecially when considering the incorporation of expensive biological reagents (cf. carbon paste systems). Mass manufacturing does however open an avenue to the production of disposable electrodes that can overcome the fouling and surface deactivation effects that repeated analysis can bring. The batch production of near identical sensors can therefore minimise the reproducibility problems associated with the regeneration of conventional electrochemical detectors [110-118]. Some of the applications are detailed in Table 6

The screen-printed electrodes can be integrated into conventional flow systems - operating under planar or the wall jet schemes outlined in Fig. 1. The latter method is highlighted in the analysis of hydrogen peroxide on a copper-modified screen-printed carbon electrode [118]. The radial flow of the analyte across the wall of the electrode minimises the diffusion layer which amplifies the signal and can give a significant advantage over the planar arrangement.

\section{Diamond electrodes}

The increasing availability of diamond electrodes hold much promise for electroanalytical applications as they can offer substantial advantages over conventional glassy carbon or HOPG systems [119-123]. They generally possess a much wider electrochemical window in aqueous and non-aqueous media. It has also been shown that polar molecules adsorb less at the surface and, as such, the electrode operating lifetime can be significantly greater than that achievable with conventional carbon surfaces. It has been shown that the repeated oxidation of catechol can be achieved without the cumulative loss in sensitivity that occurs in biological matrices [119]. Boron-doped diamond also demonstrates a marked insensitivity to dissolved

Table 7 Applications of diamond electrodes in flow systems

\begin{tabular}{llrr}
\hline Analyte & Applications & Detection limit $(\mu \mathrm{M})$ & Ref \\
\hline Azide ions & Azide detection & 0.004 & {$[119]$} \\
Dopamine (in presence of AA) & Dopamine detection & 0.0025 & {$[119]$} \\
Histamine and sulpha drugs & Histamine and sulphadiazine detection & N/A & {$[120]$} \\
Chlorophenols and theophylline & Theophylline and chlorophenols detection & 0.5 & {$[122]$} \\
\hline
\end{tabular}


oxygen and thereby provides a significant improvement over glassy carbon or HOPG when considering cathodic operations [120]. A range of applications in which the performance of boron-doped diamond electrodes has been investigated are compared and contrasted in Table 7.

\section{Future directions}

It is clear that carbon possesses considerable flexibility in its ability to be modified and effectively tailored to specific applications and stands in contrast to the more limited options available when considering metallic electrodes. These features have been long recognised for general electroanalytical investigations but are now increasingly finding application as detectors in flow systems. While bare carbon substrates were once the default option in electrochemical detection, the modified systems are capable of significantly enhancing performance. This has been demonstrated by the use of diamond and nanotube composite electrodes which can extend the range of accessible analytes and the sensitivity of the resulting response. The requirement for miniaturised systems has seen the introduction of carbon within micro-analytical systems and labon-a-chip prototypes [87, 98, 97].

Dual electrode systems have long been used in flow systems and have been reported to offer considerable advantages over conventional single-electrode configuration [124-127] detailed in Fig. 1. The couple essentially acts as generator-collector systems in which it can offer two advantages - the product of the first electrode process may provide a more easily quantifiable signal than the parent compound (i.e. it may be detected at a potential where there are few interference-especially in complex matrices where co-elution of species may be a factor) [128, 129]. Depending on the arrangement within the cell-the electrode can also be set up to induce repeated redox cycling between oxidised and reduced states and thereby offer tremendous gains in sensitivity [126-130]. These early designs were largely developed using metal electrode systems [124-127] but carbon has steadily made inroads to this area [128-134] and the use of micro-arrays is a future addition in which the main gain is the possibility of multiparametric detection within a single sample.

Issues over fouling and the consequent compromises that occur in terms of reproducibility could be countered through the adoption of screen-printed detectors. It could be envisaged that these could be integrated within conventional LC architectures but, more importantly, their inherent disposability could herald an opportunity for the fabrication of stand-alone miniaturised chip-sensorbased systems. These could eventually induce the transfer of the more traditional laboratory-based LC to decentral- ised testing environments. A diverse range of applications is apparent from the various tables and it can be seen that carbon, as the core sensing detection element, can have a significant impact on a highly varied range of chemicals that cross the agri-food, biomedical, environmental and industrial sectors.

\section{References}

1. Erickson BE (2000) Anal Chem 72:353A

2. Acworth IN, Gamache PH (1997) Am Lab 29:15

3. Baldwin RP (1999) J Pharm Biomed Anal 19:69-81

4. Lau YY, Hanson GD, Ichpurani N (1996) J Chrom B 683:209

5. Ranta VP, Hämäläinem KM, Aureola S, Urti A (1998) J Chrom B 709:1

6. Peñalver A, Pocurrull E, Borrull F, Marçé RM (2002) J Chrom A 964:153

7. Papa-Louis A, Pascalidou S (1998) Anal Biochem 263:176

8. Delgado-Zamarreňo MM, Bustamante-Rangel M, García-Jiménez M, Sánchez-Pérez A, Carabias-Martínez R (2006) Talanta 70:1094

9. Blazewicz A, Fijalek Z, Warowana-Gréskiewicz M, Boruta M (2007) J Chrom A 1149:66

10. Zhou X, Zheng C, Huang J, You T (2007) Anal Sci 23:705

11. Mikelova R, Baloun J, Petrova J, Adam V, Havel L, Petrek J, Horna A, Kizek R (2007) Bioelectrochemistry 70:508

12. Narita M, Maurakami K, Kauffmann JM (2007) Anal Chim Acta 588:316

13. Xu H, Zhang W, Wang D, Zhu W, Jin L (2007) J Chrom B 846:14

14. Rancan M, Rossi S, Sabatini AG (2006) J Chrom A 1123:60

15. D’Avloio A, Sciandra M, de Requena DG, Ibanez A, Bonora S, Di Perri G (2006) Ther Drug Monit 28:110

16. P'erez I, Montes S, Boll MC, Ram'irez J, R'ios C (2004) J Chrom B 806:133

17. Zhang GF, Maudens KE, Storozhenko S, Mortier KA, Van der Straeten D, Lambert WE (2003) J Agric Food Chem 21:7872

18. Ndaw S, Bergaentzle M, Aoude-Werner D (2003) J Chrom A 928:77

19. Takeuchi T, Aspanut Z, Imui TA, Lim LW (2007) J Chrom A 1147:42

20. Lee MS, Hook DJ, Kerns EH, Volk JK, Rosenberg IE (1993) Biol Mass Spectrom 22:84

21. Yap BK, Johnston GAR, Kazlauskas R (1992) J Chrom 573:183

22. Engel E, Ratel J (2007) J Chrom A 1154:331

23. Murugaiyah V, Chan KL (2007) J Chrom B 852:138

24. Wang Y, Al-GAzzar A, Seibert C, Sharif A, Lane C, Griffiths WJ (2006) Biochem Soc Trans 34:1246

25. Friedrich JM, Ponce-de-León C, Reade GW, Walsh FC (2004) J Electroanal Chem 561:203

26. Banks CE, Compton RG (2006) Analyst 131:15

27. Moore RR, Banks CE, Compton RG (2004) Analyst 129:755

28. Lawrence J, Robinson KL, Lawrence NS (2007) Anal Sci 23:673

29. Banks CE, Compton RG (2005) Anal Sci 21:1263

30. Krizkova S, Beklova M, Pikula J, Adam V, Horna A, Kizek R (2007) Sensors 7:1271

31. Paixao TRLC, Kosminsky L, Bertotti M (2002) Sens Act B $87: 41$

32. Gu HY, Yu AM, Chen HY (2001) Anal Lett 34(13):2361

33. Liu S, Miller B, Chen A (2005) Electrochem Comm 7:1232 
34. Di J, Zhang F (2003) Talanta 60:31

35. Florescu M, Brett CMA (2005) Talanta 65:306

36. Farhadi K, Karimpour A (2007) Anal Sci 23:479

37. Vakurov A, Simpson CE, Daly CL, Gibson TD, Millner PA (2004) Biosens Bioelectron 20:1118

38. Tao Y, Lin ZJ, Chen XM, Chen XI, Wang XR (2007) Anal Chim Acta 594:169

39. Thorogood CA, Wildgoose GG, Crossley A, Jacobs RMJ, Jones JH, Compton RG (2007) Chem Mater 19:4964

40. Chen S, Yuan R, Chai Y, Zhang L, Wang N, Li X (2007) Biosens Bioelectron 22:1268

41. Wang H, Zhang A, Cui H, Liu D, Liu R (2000) Microchem J 64:67

42. Wang HS, Ju HX, Chen HY (2002) Anal Chim Acta 461:243

43. Lin XQ, Jin GP (2005) Electrochim Acta 50:3210

44. Li X, Wan Y, Sun C (2004) J Electroanal Chem 569:79

45. Kotkar RM, Desai PB, Srivastava AK (2007) Sens Act B 124:90

46. Morita K, Shimizu Y (1989) Anal Chem 61:159

47. Tokuda K, Morita K, Shimizu Y (1989) Anal Chem 61:1763

48. Dayton MA, Brown JC, Stutts KJ, Wightman RM (1980) Anal Chem 52:946

49. Shimizu Y, Morita K (1990) Anal Chem 62:1498

50. Kang HM, Yoom TH, Bump M, Riffle JS (2001) J App Polymer Sci 79:1042

51. Chiu HT Lin JS (1992) J Mater Sci 27:319

52. Dilsiz N, Ebert E, Weisweiler W, Akovali G (1995) J Colloid Interface Sci 179:241

53. Bendikov TA, Miserendino S, Tai YC, Harmon TC (2007) Sens Act B 123:127

54. Zhang L (2007) Electrochim Acta 52:6969

55. Rubianes MD, Rivas GA (2003) Anal Lett 36:329

56. Wildgoose GG, Henry C, Leventis HC, Davies IJ, Crossley A, Lawrence NS, Jiang L, Jones TGJ, Compton RG (2005) J Mater Chem 15:2375

57. Yu J, Liu S, Ju H (2003) Biosens Bioelectron 19:401

58. Ugo P, Zangrando V, Moretto LM, Brunetti B (2002) Biosens Bioelectron 17:479

59. Ugo P, Moretto LM, De Boni A, Scopece P, Mazzocchin GA (2002) Anal Chim Acta 474:147

60. Sbaï M, Essis-Tome H, Gombert U, Breton T, Pontié M (2007) Sens Act B 124:368

61. Sadeh A, Sladkevich S, Gelman F, Prikhodchenco P, Baumberg I, Berezin O, Lev O (2007) Anal Chem 79:5188

62. Bismarck A, Lee AF, Saraç AS, Schulz E, Wilson K (2005) Compos Sci Technol 65:1564

63. Wildgoose GG, Leventis HC, Davies IJ, Crossley A, Lawrence NS, Jiang L, Jones TGJ, Compton (2005) J Mater Chem 15:2375

64. Kim TH, Park SM (2005) Electrochim Acta 50:1461

65. Nassef HM, Radi AE, O'Sullivan CK (2006) Electrochem Comm 8:1719

66. Gómez-Caballero A, Goicolea MA, Barrio RJ (2005) Analyst 130:1012

67. Zou Y, Sun LX, Xu F (2007) Biosens Bioelectron 22:2669

68. Wang Z, Zhu ZZ, Li HL (2007) Acta Chim Sinica 65(12):1149

69. Luo X, Killard AJ, Smyth MR (2007) Chem Eur J 13:2138

70. Chen Y, Yuan J, Tian C, Wang X (2004) Anal Sci 20:507

71. Wei M, Sun DM (2007) Chin J Anal Chem 35:66

72. Tanase I, Nidelea M, Buleandre W (2003) Rev Chim 54:202

73. Nagels LJ, Staes E (2001) TRAC 20:178

74. Qu F, Yang M, Jiang J, Shen G, Yu R (2005) Anal Biochem 344:108

75. Mousavi Z, Bobacka J, Ivaska A (2005) Electroanalysis 17:1609

76. Takashima W, Kaneto K (2004) Sens Act B 102:271

77. Zhang G, Yang F (2007) Electrochim Acta 52:6595
78. Oukil D, Makhloufi L, Saidani B (2007) Sens Act B 123:1083

79. Li G, Wang Y, Xu H (2007) Sensors 7:239

80. Heung Y, Bange A, Heineman WR, Halsall HB, Shanov VN, Dong Z, Pixley S, Behbehani M, Jazieh A, Tu Y, Wong DKY, Bhattacharya A, Schulz MJ (2007) Sens Act B 123:177

81. Li Y, Wang P, Wang L, Lin X (2007) Biosens Bioelectron 22:3120

82. Hamdi N, Wang J, Monbouquette HG (2005) J Electroanal Chem 58:258

83. Li J, Lin X (2007) Sens Act B 124:486

84. Malinauskas A, Kuzmarskytè J, Meškys R, Ramanavičius A (2004) Sens Act B 100:387

85. Takagi K, Shikata S (2004) Anal Chim Acta 505:189

86. Shi GY, Yamamoto K, Zhou TS, Xu F, Kato T, Jin JY, Jin LT (2003) Electrophoresis 24:3266

87. Mao L, Yamamoto K (2000) Anal Chim Acta 415:143

88. Liu Z, Niwa O, Horiuchi T, Kurita R, Torimitsu K (1999) Biosens Bioelectron 14:631

89. Shahrokhian S, Fotouhi L (2007) Sens Act B 123:942

90. Estévez-Hernández O, Naranjo-Rodríguez I, Hidalgo de Cisneros JL, Reguera E (2007) Sens Act B 123:488

91. Cai XH, Ogorevc B, Tavcar G, Kalcher K (1995) Electroanalysis 7:639

92. Ghiaci M, Rezaei B, Kalbasi RJ (2007) Talanta 73:37

93. Dong S, Zhang S, Cheng X, He P, Wang Q, Fang Y (2007) J Chrom A 1161:327

94. Apetrei C, Gutierez F, Podrígez-MéJ ML, de Saja A (2007) Sens Act B 121:567

95. Wang H, Zhang A, Cui H, Liu D, Liu R (1998) Microchem J 59:448

96. Szymańska I, Radecka H, Radecki J, Gale PA, Warriner CN (2006) J Electroanal Chem 591:223

97. Pividori MI, Alegret S (2005) Anal Lett 38:2541

98. Jayasri D, Narayanam SS (2007) J Hazard Mater 144:248

99. Zhang Y, Zheng JB (2007) Electrochim Acta 52:7210

100. Thorogood CA, Wildgoose GG, Jones JH, Compton RG (2007) New J Chem 31:958

101. Moghaddam AB, Ganjali MR, Dinarvand R, Norouzi P, Saboury AA, Moosavi-Movahedi AA (2007) Biophys Chem 128:30

102. Chakraborty S, Raj CR (2007) Electrochem Comm 9:1323

103. Gong K, Dong Y, Xiong S, Chen Y, Mao L (2004) Biosens Bioelectron 20:253

104. Deo RP, Wang J (2004) Electrochem Comm 6:284

105. Salimi A, MamKhezri H, Hallaj R, Zandi S (2007) Electrochim Acta 52:6097

106. Liu X, Wong DKY (2007) Anal Chim Acta 549:184

107. Hart JP, Crew A, Crouch E, Honeychurch KC, Pemberton RM (2004) Anal Lett 37:789

108. Manso J, Mena ML, Yánez-Sedeño P, Pigarrón J (2007) J Electroanal Chem 603:1

109. Nguyen LH, Phi TV, Phan PQ, Vu HN, Nguyen-Duc C, Fossard F (2007) Physica E 37:54

110. Miserere S, Lerdru S, Ruillé N, Griveau S, Boujtita M, Bedioui F (2006) Electrochem Comm 8:238

111. Ledru S, Ruillé N, Boujtita M (2006) Biosens Bioelectron 21:1591

112. Tanimoto de Alburquerque TD, Ferreira LF (2007) Anal Chim Acta 596:210

113. Li G, Liao JM, Hu GQ, Ma NZ, Wu PJ (2005) Biosens Bioelectron 20:2140

114. Zhang C, Gao Q, Aizawa M (2001) Anal Chim Acta 426:33

115. Zen JM, Tsai DM, Kumar AS (2003) Electroanalysis $15: 1171$

116. Gao Q, Ma Y, Cheng ZL, Wang WD, Yang MR (2003) Anal Chim Acta 488:61 
117. Zen JM, Chen PM, Kumar AS (2002) Electroanalysis 14:513

118. Zen JM, Chung HH, Kumar AS (2000) Analyst 125:1633

119. Granger MC, Xu J, Strojek JW, Swain GM (1999) Anal Chim Acta 397:145

120. Rao TN, Fujishima A (2000) Diamond Relat Mater 9:384

121. Witek MA, Swain GM (2001) Anal Chim Acta 440:119

122. Fujishima A, Rao TN (2001) Diamond Relat Mater 10:1799

123. Compton RG, Foord JS, Marken F (2003) Electroanalysis 15:1349

124. Brooks SA, Kenedy RT (1997) J Electroanal Chem 436:27

125. Peng WF, Li HM, Wang E (1994) J Electroanal Chem 375:185

126. Lai CCJ, Chen CH, Ko FH (2004) J Chrom A 1023:143

127. Paixo TRLC, Richter EM, Brito-Neto JGA, Bertotti M (2006) Eectrochem Comm 8:9
128. Honeychurch KC, Smith GC, Hart JP (2006) Anal Chem 78: 416

129. Honeychurch KC, Hart JP (2007) Electroanalysis 19:2176

130. Liu ZM, Niwa O, Kurita R, Horiuchi T (2000) Anal Chem $72: 1315$

131. Hoogvliet JC, Reijn JM, Vanbennekom WP (1991) Anal Chem 63:2418

132. Kovarik ML, Torrence NJ, Spence DM, Martin S (2004) Analyst 129:400

133. Okuno J, Maehashi K, Matsumoto K, Kerman K, Takamura Y, Tamiya E (2007) Electrochem Comm 9:13

134. Vanderveer WR, Woodward DJ, Fritsch I (2003) Electrochim Acta $48: 3341$ 